\title{
GANGGUAN BERBAHASA PADA ANAK DENGAN CIRI ATTENTION DEFICIT HYPERACTIVITY DISORDER(ADHD)
}

\author{
Tri Pujiati ${ }^{1}$, Dien Mardiana Yulianti ${ }^{2}$ \\ ${ }^{1}$ SPs UPI Bandung, Indonesia \\ ${ }^{2}$ UIN Syarif Hidayatullah Jakarta, Indonesia \\ E-mail: 1tri_pujiati@student.upi.edu, 2diendadiana1107@gmail.com
}

\begin{abstract}
Language disorders are often experienced by children, especially with Attention Deficit Hyperactivity Disorder (ADHD). Using qualitative descriptive and case study methods, this study examines the language disorder or S-LI (Speech or Language Impairment) on Student $X$ with $A D H D$. The results of the study show that (1) the language disorders which experienced by Student $X$ are phonology and pragmatic. Phonological impairments are adding phonemes $\mathrm{l} / \mathrm{h}$, phoneme omitted, and phoneme changed in some specific words. The pragmatic impairments are difficulties to communicate and to understand speech and most of the time Student $X$ have miscommunication when he made a conversation; (2) language disorder that occurs in the Student $X$ because he has Attention Deficit Hyperactivity Disorder (ADHD) traits and he was born on six month pregnancy (premature); and (3) Student X can be given speech therapy to provide special services such as peer tutors and learning models with repetitive reading techniques and appropriate speech pronunciation. Language disorder that experienced by Student $X$ is a serious problem and should be solved immediately because it can affect the acquisition of other language skills. Moreover, Student $X$ will be difficult to understand the lessons according to the curriculum in the school.
\end{abstract}

Keywords: Language Impairment; ADHD; Phonology; Pragmatics; Speech Therapy

Abstrak: Gangguan berbahasa sering dialami anak-anak, khususnya pada penderita Attention Deficit Hyperactivity Disorder (ADHD). Dengan menggunakan metode kualitatif deskriptif dan studi kasus, penelitian ini mengkaji gangguan berbahasa atau S-LI (Speech or Language Impairment) pada Siswa X yang menderita ADHD. Hasil penelitian menunjukkan bahwa (1) gangguan bahasa yang dialami Siswa $\mathrm{X}$ adalah permasalahan fonologi dan pragmatik. Permasalahan bahasa pada tataran fonologi yang dialami oleh Siswa X, seperti pada penambahan fonem $/ \mathrm{y} /$, penghilangan fonem, dan perubahan fonem pada kata-kata tertentu. Gangguan pragmatik yang dialami oleh Siswa $\mathrm{X}$ adalah kesulitan untuk berkomunikasi dan memahami ujaran dengan baik serta sering terjadi miskomunikasi pada saat berbicara; (2) gangguan berbahasa yang terjadi pada Siswa X karena ia memiliki ciri Attention Deficit Hyperactivity Disorder (ADHD) dan terlahir prematur 6 bulan; dan (3) terapi wicara yang bisa diberikan kepada Siswa X adalah dengan memberikan layanan khusus berupa tutor sebaya dan model pembelajaran teknik membaca berulang-ulang serta pengucapan ujaran yang tepat. Gangguan berbahasa pada Siswa X merupakan masalah serius dan harus segera ditangani karena dapat berdampak pada penguasaan keterampilan berbahasa lainnya. Tidak hanya itu, Siswa X akan mengalami kesulitan dalam memahami pelajaran yang diberikan sesuai kurikulum di sekolah tersebut.

Kata Kunci: gangguan berbahasa; ADHD; fonologi; pragmatik; terapi wicara

Permalink/DOI: http:/ /dx.doi.org/10.15408/dialektika.v5i1.6005 


\section{Pendahuluan}

Perkembangan bahasa pada anak menjadi tolok ukur bahwa anak tersebut memiliki perkembangan bahasa yang normal sehingga dalam kehidupan sosialnya anak dapat berinteraksi dengan baik. Bahasa merupakan landasan seorang anak untuk dapat mempelajari sesuatu yang ada di lingkungannya. ${ }^{1}$ Keterampilan berbahasa berhubungan erat dengan perkembangan kognitif setiap anak. Pada perkembangan kognitif anak, gangguan bicara dan bahasa adalah salah satu penyebab gangguan perkembangan yang paling sering ditemukan pada anak. ${ }^{2}$ Secara khusus, gangguan kognitif bisa menimbulkan penurunan kognitif dalam pengembangan bahasa dan kemampuan komunikasi pada anakanak. $^{3}$

Perkembangan bahasa pada anak dikatakan mengalami permasalahan jika penggunaan bahasanya tidak seperti anak-anak sebayanya. Permasalahan yang sering muncul pada anak usia prasekolah maupun usia sekolah adalah gangguan berbahasa yang sering disebut SLI atau speech or language impairment. Gangguan semacam ini dapat berdampak pada kemampuan dalam pembelajaran di kelas. American Speech-Language-Hearing Association (ASHA) mendefinisikan SLI sebagai sebuah gangguan bahasa yang mencakup pemahaman dan/atau penggunaan bahasa lisan, tertulis dan/atau simbol lain. Gangguan tersebut mungkin melibatkan (1) bentuk bahasa seperti (fonologi, morfologi, sintaksis), (2) isi bahasa (semantik), dan/atau (3) fungsi bahasa dalam komunikasi (pragmatik). ${ }^{4}$

Gangguan bahasa seperti SLI sering dialami anak dengan ciri ADHD (Attention Deficit Hyperactivity Disorder), yaitu adanya pola yang menetap dari kurang perhatian yang disertai hiperaktivitas. Gejala ini dapat diketahui sebelum usia 7 tahun dan dapat terjadi dalam berbagai macam situasi seperti situasi rumah, sekolah, bermain, atau situasi sosial lainnya. ${ }^{5}$ Selain itu, gangguan

\footnotetext{
${ }^{1}$ Khoiriyah, dkk., "Model Pengembangan Kecakapan Berbahasa Anak yang Terlambat Berbicara (Speech Delay)”, Jurnal Ilmiah Mahasiswa Pendidikan Anak Usia Dini, Vol. 1, No. 1, Agustus 2016.

${ }^{2}$ Sunanik dalam Nadwa, "Pelaksanaan Terapi Wicara dan Terapi Sensori Integrasi pada Anak Terlambat Bicara”, Jurnal Pendidikan Islam, Vol. 7, Nomor 1, April 2013.

${ }^{3}$ Louise Cummings, Clinical Linguistics, (Edinburgh University Press: Edinburgh, 2008), h. 129.

${ }^{4}$ Lei Sun dan Geraldin P. Wallach, "Language Disorders Are Learning Disabilities Challenges on the Divergent and Diverse Paths to Language Learning Disability", Top Lang Disorders, Vol. 34, No.1, Januari/Maret 2014.

${ }^{5}$ Iffa Hikmawati dan Erni Hidayati, "Efektivitas Terapi Menulis untuk Menurunkan Hiperaktivitas dan Impulsivitas pada Anak dengan Attention Deficit Hyperactivity Disorder (ADHD)” EMPATHY, Jurnal Fakultas Psikologi, Vol. 2, No 1, Juli 2014.
} 
ADHD ini juga dapat menimbulkan masalah dalam perkembangan kemampuan berbahasa. $^{6}$

Fakta empirik dari beberapa penelitian terdahulu menunjukkan bahwa anak dengan diagnosis ADHD memiliki permasalahan dalam berbahasa. Penelitian Alyssa, dkk. menunjukkan bahwa anak-anak dengan ADHD memiliki masalah dalam pemahaman bahasa, mengikuti petunjuk dan konsep pemahaman, dan memahami hubungan gramatikal. Secara ekspresif, anak-anak dengan $\mathrm{ADHD}$ mengalami kesulitan dalam merumuskan kalimat, mengingat kata-kata dengan cepat, dan melakukan asosiasi kata tugas. Dalam keterampilan ingatan, anak-anak dengan ADHD memiliki kinerja buruk dalam tugas mengingat/mempertahankan materi. ${ }^{7}$ Penelitian Safaa menunjukkan bahwa gangguan berbahasa (LI atau Language Impairment) adalah permasalahan yang sangat umum pada anak-anak dengan diagnosis ADHD. ${ }^{8}$

Penelitian ini bermula dari informasi guru di MI Nur As-Sholihat yang memiliki murid dengan gangguan berbahasa di kelas 1, yaitu Siswa X. Siswa ini memiliki gangguan berbahasa SLI (Speech Language Impairment) yang berdampak pada penurunan nilai belajar yang selalu di bawah KKM (Kriteria Ketuntasan Minimal) pada semua mata pelajaran. Meski saat ujian guru membacakan soal, nilai yang dihasilkan masih di bawah KKM. Pengamatan yang dilakukan guru menunjukkan bahwa saat menjawab pertanyaan secara lisan, Siswa X berpikir lama dalam menjawab serta jawaban yang diberikan selalu tidak sesuai dengan pertanyaan yang diberikan. Berdasarkan observasi dan pengamatan awal, peneliti mendapatkan informasi dari guru tersebut bahwa Siswa X mendapat gangguan berbahasa dengan ciri ADHD (Attention Deficit Hyperactivity Disorder) sehingga anak sulit fokus dan kurang perhatian terhadap pembelajaran.

Berdasarkan permasalahan gangguan berbahasa seperti SLI pada anak dengan diagnosis $\mathrm{ADHD}$, penelitian ini berupaya untuk mengisi gap penelitian terdahulu dengan menggunakan subjek penelitian Siswa X yang berciri ADHD. Siswa $\mathrm{X}$ bisa dikatakan bermasalah karena perkembangan bahasa yang dimiliki berbeda dengan anak pada usianya. Anak dikatakan terlambat bicara apabila

${ }^{6}$ Dita, dkk, "Prevalensi Gangguan Pemusatan Perhatian dan Hiperaktivitas pada Siswa dan Siswi Sekolah Dasar Negeri Kecamatan Padang Timur Kota Padang Tahun 2013”, Jurnal Kesehatan Andalas, Vol. 3, No. $2,2014$.

${ }^{7}$ Alyssa, dkk., "Prevalence and Nature of Language Impairment in Children with Attention Deficit/Hyperactivity Disorder”, Contemporary Issues in Communication Science and Disorders, Vol. 38, 2011.

${ }^{8}$ Safaa R. El Sady, dkk, "Language Impairment in Attention Deficit Hyperactivity Disorder in Preschool Children”, The Egyptian Journal of Medical Human Genetics, Vol. 14, Issues 4, Oktober 2013. 
tingkat perkembangan bicara berada di bawah tingkat kualitas perkembangan bicara anak sebaya ini dapat diketahui dari ketepatan penggunaan kata. ${ }^{9} \mathrm{Hal}$ ini sejalan dengan pemaparan dari Atchinson tentang tahap kemampuan bahasa anak yang disajikan pada tabel $1 .^{10}$

Tabel 1. Tahap Kemampuan Berbahasa Menurut Atchinson

\begin{tabular}{ll}
\hline Tahap Perkembangan Bahasa & Usia \\
\hline Menangis & Lahir \\
Mendekur (menghasilkan vokal tetapi tidak jelas) & 6 minggu \\
Meraban (menghasilkan vokal dan konsonan) & 6 bulan \\
Pola intonasi & 8 bulan \\
Tuturan satu kata & 1 tahun \\
Tuturan dua kata & 18 bulan \\
Infleksi kata & 2 tahun \\
Kalimat tanya dan ingkar & $21 / 4$ tahun \\
Konstruksi yang jarang dan kompleks & 5 tahun \\
Tuturan yang matang & 10 tahun \\
\hline
\end{tabular}

Berdasarkan tabel di atas, Siswa X yang berusia 11 tahun seharusnya memiliki kemampuan berbahasa yang matang terutama pada masalah tuturan atau pragmatik. Namun, Siswa $\mathrm{X}$ justru sebaliknya, dia mengalami permasalahan pada penuturan ucapan dan sering gagal memberikan jawaban atas pertanyaan yang diberikan oleh kawan tuturannya.

Problematika umum yang diangkat pada penelitian studi kasus ini adalah gangguan bahasa yang dialami oleh anak dengan ciri ADHD pada kasus yang dialami subjek tertentu. Secara spesifik, hasil penelitian ini berupaya untuk menjawab pertanyaan penelitian berikut (1) bagaimana gangguan bahasa yang dialami anak dengan ciri ADHD (Attention Deficit Hyperactivity Disorder)? (2) apa penyebab terjadinya gangguan berbahasa pada anak dengan ciri ADHD (Attention Deficit Hyperactivity Disorder? dan (3) bagaimana upaya klinik terapi untuk penyembuhan gangguan berbahasa pada anak dengan ciri ADHD (Attention Deficit Hyperactivity Disorder)? Hasil penelitian ini diharapkan mampu memberikan solusi praktis bagi praktisi bahasa, guru, dan orang tua dalam memberikan penanganan bahasa bagi anak yang mengalami gangguan berbahasa atau SLI (Speech Language Impairment) dengan ciri ADHD (Attention Deficit Hyperactivity Disorder).

\footnotetext{
${ }^{9}$ Elizabeth B Hurlock, Perkembangan Anak Jilid 1, (Jakarta: Erlangga, 1978), h. 194-196.

${ }^{10}$ Atchinson dalam A. Kholid dan Andika Dutha Bachari, Dasar-Dasar Psikolinguistik, (Bandung: UPI Press, 2009), h. 50-56.
} 


\section{Metode}

\section{Desain \& Teknik Penelitian}

Penelitian ini menggunakan metode deskriptif kualitatif karena peneliti memberikan data berupa deskripsi kualitatif berkaitan dengan fenomena yang diperoleh di lapangan berupa gangguan berbahasa (speech language impairment) pada anak usia 11 tahun. Penelitian ini memberikan gambaran terhadap data yang diperoleh dari hasil penelitian lapangan yang telah ditemukan pada subjek tertentu. Subjek penelitian yang dipilih adalah subjek yang mengalami gangguan berbahasa akibat gangguan pada pemusatan perhatian dan hiperaktivitas.

Jenis penelitian yang digunakan adalah pendekatan studi kasus sehingga tahapan-tahapan penelitian mengikuti tahapan studi kasus. Studi kasus merupakan pengujian secara rinci terhadap suatu latar (a detailed examination of one setting) atau satu orang subjek (one single subject) atau satu tempat penyimpanan dokumen (one singel depository of documents) atau satu peristiwa tertentu (one particular event). ${ }^{11}$

Terkait dengan penelitian studi kasus, terdapat enam prosedur yang harus dilalui dalam penelitian tersebut, yaitu: (1) identifikasi kasus, tahapan ini merupakan awal dimulainya penelitian studi kasus. Pada tahapan ini, peneliti mencoba mengenali atau mendeteksi sebuah kasus; (2) identifikasi masalah, pada tahapan ini peneliti menentukan masalah pada kasus tersebut; (3) diagnosis, pada tahapan ini peneliti mulai menentukan bentuk masalah berupa kelainan atau ketidakmampuan, (4) prognosis, pada tahapan ini peneliti mencoba meramalkan akibat yang akan dialami oleh siswa yang memiliki kasus tersebut; (5) remedial, tahapan ini berupaya melakukan penyembuhan atau perbaikan pada siswa yang memiliki kasus; dan (6) evaluasi, peneliti mengadakan sebuah evaluasi akhir dengan mempertimbangkan hasil yang didapat dari lima tahapan sebelumnya.

Teknik pengumpulan data dilakukan dengan teknik rekam dan wawancara. Teknik rekam digunakan untuk merekam aktivitas dari subjek penelitian dan mengidentifikasi kesulitan-kesulitan berbahasa yang dialami subjek penelitian. Wawancara dilakukan oleh peneliti dengan memberikan pertanyaan terbuka kepada orang tua dan guru yang mengajar di kelas subjek tersebut.

${ }^{11}$ Syamsuddin \& Damaianti, Metode Penelitian Pendidikan Bahasa, (Bandung: Remaja Rosdakarya, 2009), 


\section{Sumber \& Subjek Penelitian}

Fokus penelitian ini pada anak usia 11 tahun dengan masalah pada gangguan berbicara (speech language impairment). Sumber data pada penelitian ini adalah subjek penelitian dan narasumber penelitian. Subjek penelitian adalah anak yang mengalami kesulitan komunikasi dan dengan ciri ADHD (Attention Deficit Hyperactivity Disorder). Subjek dalam penelitian adalah Siswa X yang berusia 11 tahun berjenis kelamin pria dan bersekolah di MI Nur As-Sholihat, Serpong. Siswa tersebut berada di kelas 1 MI dan berasal dari keluarga dengan status sosial menengah ke atas.

\section{Narasumber Penelitian}

Narasumber dalam penelitian dibagi menjadi dua karakteristik, yaitu narasumber primer dan sekunder. Narasumber primer dalam penelitian ini adalah orang tua kandung Siswa X yang memiliki waktu berbicara dan memiliki interaksi lebih rapat dengan subjek penelitian. Adapun narasumber sekunder yang dijadikan sumber informasi adalah guru sekolah yang mengajar Siswa X di MI Nur As-Sholihat, Serpong.

Narasumber primer yang pertama dalam penelitian ini adalah Ibu X yang berusia 48 tahun, bekerja sebagai seorang psikolog dan dosen. Ia beralamat di Serpong dan berasal dari status sosial menengah ke atas. Adapun narasumber primer yang kedua adalah Ayah X yang berusia 60 tahun dan bekerja sebagai purnawirawan TNI AD.

Narasumber sekunder dalam penelitian ini adalah Guru X yang berusia 21 tahun dan sedang kuliah semester 8. Guru tersebut berasal dari status ekonomi menengah ke atas dan berjenis kelamin wanita.

\section{Tempat \& Waktu Observasi}

Penelitian dilakukan di MI Nur As-Sholihat, Lengkong Wetan, Serpong, Tangerang Selatan, Banten. Kegiatan observasi dilakukan oleh peneliti pada Mei 2017. Jadwal penelitian dilakukan pada Rabu dan Jumat pukul 08.00 hingga pukul 10.00 WIB.

\section{Pembahasan}

Penelitian ini merupakan penelitian studi kasus pada Siswa X yang mengalami gangguan berbahasa. Hasil penelitian menunjukkan bahwa kasus ini berlaku pada subjek tunggal. Penelitian studi kasus ini menggunakan enam 
tahapan penelitian sehingga sampai pada tahapan evaluasi dan terapi klinik bahasa yang diberikan pada Siswa X.

\section{Identifikasi Kasus}

Subjek penelitian teridentifikasi mengalami gangguan berbahasa sejak usia 2 tahun dan dinyatakan mengalami gangguan ADHD oleh psikiater yang menangani Siswa X. Kasus yang dialami oleh subjek penelitian tidak dapat dipisahkan dari kondisi kelahirannya. Kasus yang dialami oleh Siswa X merupakan dampak dari ketidakhati-hatian orang tua. Dalam hal ini, Ibu X yang tidak mengetahui bahwa dirinya sedang mengandung anak bungsu karena ia selalu menstruasi setiap bulan. Pada saat kandungan berusia 5 bulan, Ibu X dirawat dan diagnosis menderita penyakit liver sehingga ia diberikan obat liver. Setelah 3 bulan dirawat di rumah sakit, dokter menyarankan untuk USG, barulah diketahui bahwa Ibu X sedang hamil dan usia kandungannya sudah 5 bulan. Pada saat sedang hamil 6 bulan, Ibu X berjalan-jalan di pasar dan tidak sengaja terjatuh di jalan dan bayi sudah banyak meminum darah sehingga dokter harus melakukan operasi caesar. Saat lahir, berat bayi kurang dari 500 gram. Meskipun terlahir secara prematur, kondisi fisik dan anggota badan Siswa $\mathrm{X}$ semuanya normal.

Pada saat di NICU (Neonatal Intensive Care Unit), Ibu X khawatir dengan anaknya yang terlahir prematur dan sempat berpikir bahwa anaknya mengalami autis. Namun, diagnosis dokter menyebutkan bahwa anak mengalami ADHD (Attention Deficit Hyperactivity Disorder) dan pada usia 2 tahun jelas sekali terlihat bahwa Siswa X sulit diam dan selalu bergerak kemanamana dengan cepat sehingga dia disebut anak kijang. Bahkan, Siswa X pernah hilang pada saat diajak pergi oleh orang tuanya.

\section{Identifikasi Masalah}

Masalah yang dialami oleh Siswa $\mathrm{X}$ adalah gangguan berbahasa akibat adanya ADHD (Attention Deficit Hyperactivity Disorder) yang menyebabkannya tidak dapat konsentrasi, selalu melamun, kurang fokus, selalu bercanda sehingga sulit diajak komunikasi pada saat belajar di kelas. Tidak hanya itu, Siswa X selalu menggunakan kosakata yang kurang jelas ketika berkomunikasi dan juga sering tidak nyambung ketika ditanya oleh guru Siswa $\mathrm{X}$. Kesulitan tersebut berpengaruh terhadap pemahaman siswa terhadap materi yang disampaikan oleh guru secara lisan sehingga banyak nilai yang di bawah KKM. 
Gangguan berbahasa yang dihadapi oleh Siswa X dalam berkomunikasi dapat dikategorikan pada permasalahan fonologi dan pragmatik. Permasalahan fonologi yang dihadapi oleh Siswa X adalah permasalahan saat membunyikan huruf terakhir pada kata yang diucapkan dengan menggunakan penambahan fonem [ $\mathrm{y}]$ pada akhir kata, penghilangan fonem, atau penggantian fonem [ $\mathrm{y}]$ pada huruf terakhir pada sebuah kata. Tidak hanya itu, Siswa X sering menghilangkan fonem pada saat berkomunikasi. Permasalahan pada pragmatik yang dialami oleh Siswa $\mathrm{X}$ adalah tidak dapat menyebutkan runtutan ujaran dengan baik dan sering tidak nyambung dengan pertanyaan yang diberikan oleh lawan tutur.

\section{Permasalahan Fonologi}

Berikut ini data yang menunjukkan gangguan berbahasa pada tataran fonologi yang dialami oleh Siswa X pada saat berkomunikasi. Berikut ini data yang menunjukkan kesalahan berbahasa yang disampaikan oleh Siswa X dengan menambahkan fonem [y] pada huruf terakhir.

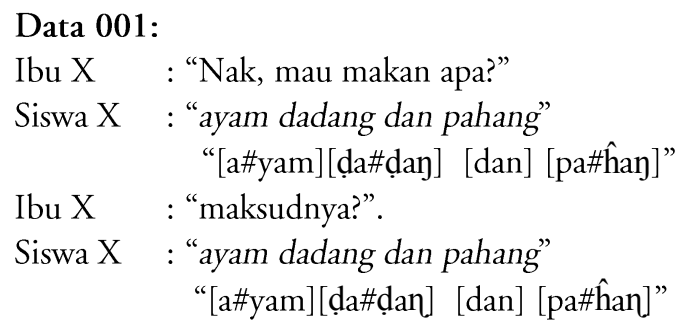

Pada data 001, dapat dilihat percakapan yang dilakukan oleh Ibu X yang menanyakan kepada Siswa X makanan yang ingin ia makan. Kemudian, Siswa X mengatakan bahwa ia ingin makan ayam dada dan ayam paha. Permasalahan fonologi yang tampak terlihat pada data di atas yaitu pada penambahan fonem $/ \mathrm{y} /$, pada huruf terakhir pada kata [dada] dan [paha] sehingga bunyi suara yang

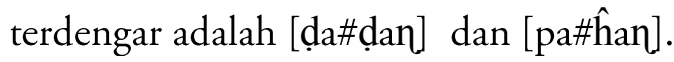

Berikut ini data yang menunjukkan kesalahan berbahasa yang disampaikan oleh Siswa X dengan menggantikan fonem /h/ menjadi /y/.

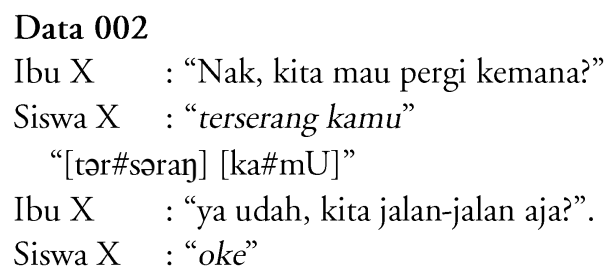




$$
\text { “[oke]" }
$$

Pada data 002, terlihat gangguan berbahasa dengan masalah fonologi yang dihadapi oleh Siswa X. Pada saat mengatakan kata [terserah], ia mengganti fonem $/ \mathrm{h} /$ menjadi fonem $/ \mathrm{y} /$ sehingga suara yang terdengar adalah [tər\#səray].

Berikut ini data yang menunjukkan kesalahan berbahasa yang disampaikan oleh Siswa X dengan menghilangkan beberapa fonem dalam sebuah kata.

\section{Data 003:}

Siswa X : "Ah..ibu, jangan diitoin lagi?"

" [aĥ] [i\#bu] [ja\# yan] [di\#ito\#in] [la\#gi]"

Guru X : "gak apa apa..."

Pada data 003, dapat dilihat bahwa Siswa X mengalami gangguan berbahasa pada bidang fonologi dengan menghilangkan dan mengganti fonem dari sebuah kata. Pada pengucapan kata [difotoin], Siswa X menghilangkan fonem / $f$ / dan menggantinya dengan fonem /i/ sehingga bunyi yang terdengar adalah [di\#ito\#in].

\section{Data 004}

Guru X : "kamu kalau bulan puasa, puasa gak?”

Siswa X : "aku tak mau bulan puaca, aku laper" "[a?\#ku] [ta?] [ma\#U] [pu\#aca] - [a\#ku] [la\#per]"

(sambil lari-lari)

Guru X : "masak ga puasa?"

Siswa X : "aku puaca beati aku tatu tatu doang puaca" (sambil lari-lari) "[a?\#ku] [pu\#aca] [bə\#ati] [a?\#ku] [ta\#tu] [ta\#tu] [pu\#aca]"

Pada data 004, dapat dilihat bahwa Siswa X sulit mengucapkan fonem [s] pada kata [puasa] sehingga bunyi yang terdengar adalah [pu\#aca]. Siswa X menggantikan fonem /s/ dengan fonem /c/. Pada pengucapan [berarti], Siswa X menghilangkan fonem /r/ dan fonem / / / sehingga bunyi yang terdengar adalah [bə\#ati]. Pada pengucapan kata [satu], Siswa X mengganti fonem /s/ dengan fonem $[t]$ sehingga bunyi yang terdengar adalah bunyi [ta\#tu].

\section{Data 005 \\ Guru X : "Kamu kepalanya dibotakin siapa?” \\ Siswa X : "dipotong” (sambil tertawa) \\ "[di\#po\#ton]" \\ Guru X : "iya dipotong siapa?” \\ Siswa X : "sendirilah" (sambil teratawa)}




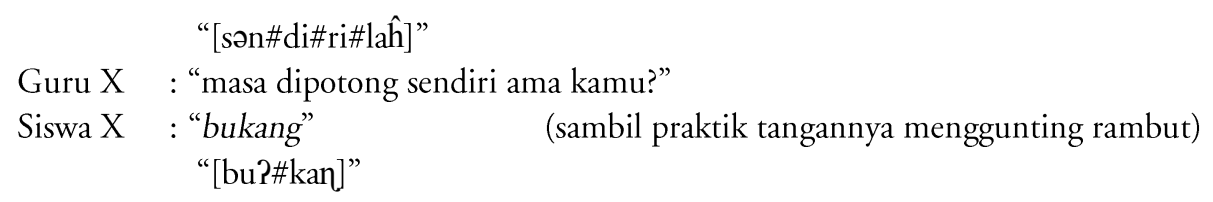

Pada data 005, terdapat penambahan fonem $/ \mathrm{y} /$ pada pengucapan kata [bu?\#kan]. Ia menambahkan fonem / $\mathrm{y} /$ pada kata 'bukan' sehingga suara yang terdengar jelas adalah [bukañ]. Tidak hanya itu, Siswa X berbicara sambil tertawa dan bergerak-gerak dan mempraktikkan cara memotong rambut dengan menggunakan gunting dan sisir rambut sehingga suara tidak jelas terdengar.

\section{Permasalahan Pragmatik}

Permasalahan terkait dengan keutuhan ujaran sering dialami oleh Siswa X. Ia sering tidak fokus ketika ditanya dan memberikan jawaban yang tidak sesuai dengan yang ditanyakan oleh lawan bicara. Berikut ini data yang menunjukkan gangguan berbahasa secara pragmatik:

\section{Data 006}

Guru X : "belajar ga semalam?"

Siswa X : "apa bu?"

$$
\text { "[a\#pa] [bu\#]" (sambil berpikir lama...) }
$$

Guru X : "kamu belajar ga semalam?”

Siswa X : "belajar" "[bə\#la\#jar]"

Guru X : "belajar apa?”

Siswa X : "belajar itu"

"[bə\#la\#jar] [i\#tu?]"

Guru X : "apa? Sekarang pelajarannya apa?”

Siswa X : "eh........ matematika (sambil berpikir lama ...)

"[ma\#tə\#ma\#ti\#ka\#]

Guru X : "ya betul matematika, sama?"

Siswa X : "buku... eh"

[bu\#ku...\#eh\#]"

Guru X : "sama buku? bukannya sama bahasa Inggris?

Pada data 006, dapat dilihat bahwa Siswa X mengalami masalah dalam memahami ujaran dan selalu berpikir lama pada saat menjawab pertanyaan yang diberikan oleh ibu guru X. Kegagalan pragmatik dapat dilihat pada contoh ujaran di atas. Pada saat ibu guru X bertanya apakah Siswa X belajar atau tidak semalam, ia mengatakan dengan bertanya balik ke gurunya dengan mengatakan [a\#pa] [bu\#]. Pada saat ditanya mata pelajaran yang sekarang sedang dipelajari, Siswa X tampak bingung dan Siswa X dapat menjawab setelah teman-temannya 
berteriak bahwa pelajaran yang ada sekarang adalah matematika. Pada saat ibu guru X bertanya mata pelajaran apa selain matematika, maka Siswa X tampak bingung dan menjawab dengan mengatakan [buku], padahal yang dimaksudkan oleh ibu guru $\mathrm{X}$ adalah pelajaran bahasa Inggris setelah matematika.

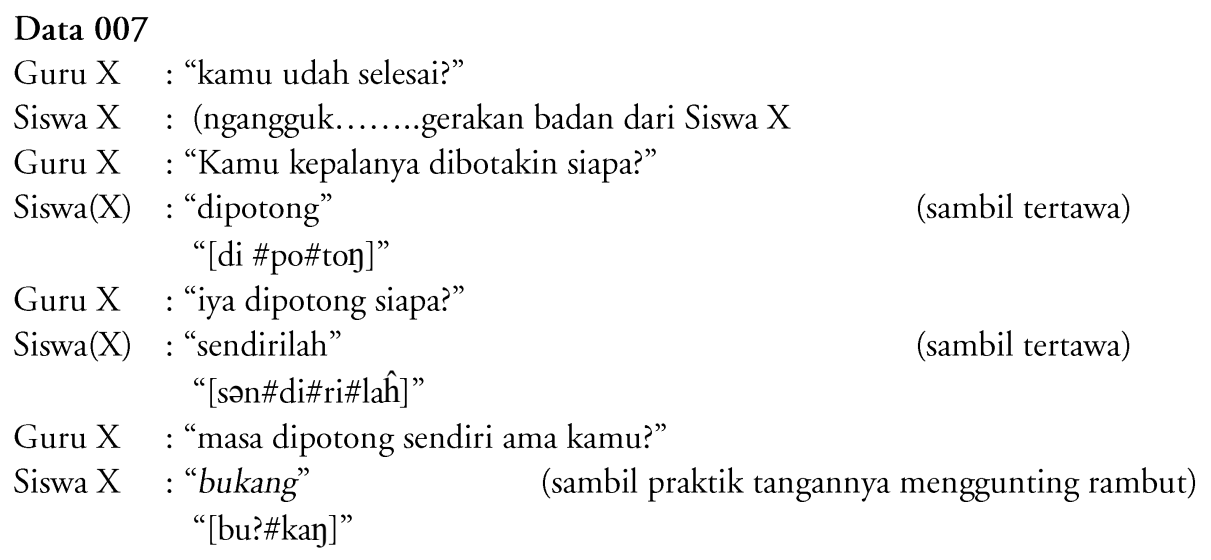

Pada data 007, dapat dilihat bahwa Siswa X menggunakan komunikasi non-verbal untuk menyampaikan maksud yang ingin disampaikan kepada gurunya. Pada saat guru X bertanya apakah Siswa X sudah selesai dalam mengerjakan soal, Siswa X mengangguk yang menandakan 'iya' dalam bahasa lisan. Komunikasi non-verbal ia gunakan untuk menyampaikan pesan bahasa kepada mitra tuturnya. Pada data di atas, dapat dilihat bahwa terdapat kesalahan dalam penyampaian ujaran, seperti pada saat guru X menanyakan siapa yang membuat kepalanya botak, namun Siswa X menanggapi dengan mengatakan "[dipoton]". Ujaran yang disampaikan oleh Siswa X belum menjawab pertanyaan guru X sehingga ibu guru X menanyakan kembali kepada Siswa X secara berulang dan baru Siswa X dapat memahami maksud ujaran dari ibu guru $\mathrm{X}$ dan menjawabnya dengan "[sən\#di\#ri\#laĥ]". Jawaban yang diberikan oleh Siswa X membuat ibu guru X penasaran dan menanyakan ulang kepada Siswa X jika ia benar memotong rambutnya sendiri, dan ia mengatakan [bu?\#kan] yang berarti bahwa ia bukan yang memotong sendiri, tetapi orang lain yang memotong. Siswa $\mathrm{X}$ juga mempraktikkan cara memotong rambut dengan gunting dan sisir rambut.

\section{Diagnosis}

Diagnosis merupakan istilah (terminology) yang diadopsi dari bidang medis. Diagnosis dapat diartikan sebagai upaya atau proses menemukan kelemahan atau penyakit (weakness, disease) yang dialami seseorang dengan 
melalui pengujian dan studi yang seksama mengenai gejala-gejalanya (symptons). Pada tahapan ini, peneliti berupaya memberikan kelemahan yang dialami oleh Siswa X berdasarkan pengamatan guru, wawancara dengan guru dan orang tua serta bertanya kepada teman-teman dari Siswa X tersebut.

\section{Prognosis}

Pada tahapan ini, peneliti memberikan dampak negatif dari permasalahan yang dihadapi oleh Siswa $\mathrm{X}$ dengan adanya gangguan berbahasa atau SLI (Speech or language impairment) yang dialami Siswa $\mathrm{X}$ tersebut terhadap kesuksesan dalam komunikasi dan juga pembelajaran di kelas. Kesulitan tersebut akan berdampak negatif langsung kepada beberapa faktor. Apabila siswa mengalami gangguan berbahasa atau SLI (Speech or language impairment), maka siswa akan sulit untuk menulis, membaca, berkomunikasi, dan menyimak. Pada saat menulis, anak akan kesulitan menulis karena bahasa yang ia kuasai kurang bagus, begitupun pada saat membaca, berkomunikasi dengan lawan bicara dan juga menyimak. Hal ini dapat dilihat pada proses pembelajaran bahwa Siswa X sulit untuk memahami komunikasi lawan bicara dan sulit menyimak materi dengan baik. Tidak hanya itu, akibat dari adanya gangguan berbahasa, Siswa X kurang maksimal dalam memahami informasi dan materi yang disampaikan oleh guru secara lisan sehingga nilai yang dicapai oleh Siswa X pasti akan menurun karena gangguan berbahasa yang ia alami berpengaruh terhadap pemahaman materi pembelajaran.

Lebih jauh, gangguan berbahasa bisa membuat Siswa X tidak percaya diri dan kurang bisa bersosialisasi dengan teman-teman sebayanya dan jika kasus gangguan berbahasa ini tidak segera mendapatkan penanganan yang serius, maka akan menggangu perkembangan kecerdasan Siswa X tersebut.

\section{Remedial}

Pada tahapan ini, peneliti memberikan tahapan remedial. Tahapan remedial yang dimaksudkan dalam penelitian adalah tahapan yang berupaya melakukan penyembuhan atau perbaikan pada Siswa X yang memiliki kasus gangguan berbahasa atau SLI (Speech or language impairment). Penyembuhan dan perbaikan tersebut dilakukan dengan melihat karakteristik kasus yang dialami Siswa X tersebut. Remedial ini diharapkan dapat memberikan solusi praktis atas gangguan berbahasa yang dialami oleh Siswa X.

Remedial dalam penelitian ini berbentuk layanan khusus dalam proses komunikasi dan pembelajaran yang menyesuaikan dengan karakteristik Siswa X. 
Seperti yang telah dipaparkan sebelumnya pada saat wawancara, guru telah memberikan bentuk layanan khusus kepada Siswa X. namun peneliti memberikan masukan remedial yang terdiri dari beberapa bentuk, antara lain dengan memberikan pendekatan kepada siswa, pendekatan kepada orang tua, pendekatan guru pada saat pembelajaran, pendekatan tutor sebaya, model pembelajaran membaca berulang-ulang, dan model pembelajaran komunikasi dengan kalimat ujaran yang tepat.

Berikut ini penjabaran terkait dengan remedial yang bisa diberikan sebagai masukan pada guru dan orang tua yang bisa diberikan kepada Siswa X sebagai upaya penyembuhan gangguan berbahasa.

Pendekatan kepada Siswa X diberikan oleh guru X agar ia tetap semangat dan memiliki motivasi yang tinggi untuk memperbaiki komunikasinya. Guru juga harus mendampingi Siswa X serta sabar dalam memberikan perhatian kepadanya agar ia merasa nyaman ketika belajar di kelas serta tidak merasa malu jika ditanya oleh guru maupun teman selama proses pembelajaran.

Orang tua sebagai orang terdekat dengannya harus tetap semangat dan yakin bahwa ia akan berubah dan bahasa yang digunakan akan semakin lebih baik seiring bertambahnya usia dan juga terapi yang sering diberikan oleh orang tua. Orang tua harus senantiasa mendorong anak untuk berbicara dengan menggunakan bahasa yang benar dan mengarahkan dengan penuh perhatian.

Guru sebagai pengajar di sekolah memiliki peran penting dalam upaya penyembuahan bahasa pada Siswa X. Guru harus memberikan monitoring serta pemahaman mendalam terhadapnya pada saat pembelajaran. Selain memberikan pelajaran tambahan di luar kelas, hendaknya guru sering mengajak berbicara pada Siswa X sehingga proses pengucapan bahasanya bisa semakin lancar. Tidak hanya itu, guru juga dapat memberikan revisi atas kesalahan ucapan kata pada Siswa X sehingga kata-kata yang salah dapat dihindari pada saat berkomunikasi.

Pendekatan berikutnya adalah tutoring dari teman sebaya dalam berkomunikasi. Pendekatan ini dapat diberikan oleh guru dengan meminta teman dekat Siswa X untuk memberikan masukan pada saat ia mengalami gangguan berbahasa atau salah dalam mengucapkan kata-kata tertentu. Tutor teman sebaya ini sangat tepat diberikan karena sebagai sesama siswa, tentunya ia lebih dekat dan sering berkomunikasi dengan teman sebayanya.

Model pembelajaran yang bisa diterapkan sebagai upaya untuk terapi gangguan berbicara yang dihadapi oleh Siswa $\mathrm{X}$ adalah dengan memberikan 
model pembelajaran dengan membaca dan berbicara dengan teknik berulang. Cara ini dilakukan pada saat proses pembelajaran, Siswa X diminta untuk membaca sesuai dengan tulisan dan lafal yang benar dan diulangi jika ia melakukan kesalahan pada saat membaca.

Model pembelajaran berikutnya adalah model komunikasi dengan kalimat ujaran yang tepat. Guru sering mengajak berkomunikasi keapada Siswa $\mathrm{X}$ dan mengajarkannya untuk menjawab sesuai dengan pertanyaan yang diberikan oleh lawan bicara. Guru juga mengajarkan bagaimana cara menjawab jika ada pertanyaan yang diberikan oleh lawan bicara. Teknik yang bisa diberikan adalah dengan mengajarkan bentuk dan jawaban atas pertanyaan tersebut dengan jawaban yang tepat. Kalimat tanya yang bisa diajarkan adalah kalimat tanya yes-no question (pertanyaan yang hanya memerlukan jawaban iya dan tidak) dan WH question (kalimat tanya yang membutuhkan jawaban berupa informasi)

\section{Evaluasi}

Tahapan evaluasi adalah tahapan terakhir yang dilakukan oleh peneliti pada penelitian studi kasus. Peneliti melakukan evaluasi akhir dengan mempertimbangkan hasil pada lima tahapan sebelumnya. Artinya pada tahapan ini dilakukan perbaikan berdasarkan data yang ada. Evaluasi merupakan tahapan untuk memberikan pertimbangan atas kasus yang dihadapi oleh subjek pada penelitian studi kasus dan berupaya memberikan terapi yang tepat terhadap gangguan bahasa pada Siswa X.

Pemaparan evaluasi pada penelitian bahwa gangguan berbahasa atau SLI (Speech or language impairment) yang dialami oleh Siswa X diakibatkan oleh ketidakfokusan anak karena ia merupakan anak dengan ciri ADHD (Attention Deficit Hyperactivity Disorder). Ia mengalami gangguan ADHD karena terlahir dengan prematur dan Ibu X yang mengkonsumsi obat-obatan liver selama masa kehamilan. Akibatnya, ia selalu tidak fokus dan gagal memberikan umpan balik pada saat berkomunikasi ketika ditanya oleh guru selama proses pembelajaran dan mengucapkan kata-kata tertentu sehingga ada beberapa penambahan atau pengurangan fonem pada saat berbicara. Sebagai upaya terapi, motivasi dari guru dan orang tua sangat berperan dalam upaya penyembuhan gangguan berbahasa yang dialaminya. Layanan yang bisa didapatkan oleh siswa X yaitu tutor sebaya dan model pembelajaran dengan teknik membaca berulang-ulang serta pengucapan ujaran yang tepat. Bentuk layanan khusus seperti ini 
mempermudah siswa dan meningkatkan kepercayaan diri Siswa X pada saat berbicara.

\section{Simpulan}

Gangguan berbahasa atau SLI (Speech or language impairment) yang dialami oleh Siswa X merupakan permasalahan bahasa yang banyak dialami oleh anak-anak pada usia tertentu. Pada studi kasus ini, SLI yang terjadi pada Siswa $\mathrm{X}$ diakibatkan oleh ketidakfokusan anak pada saat berbicara karena Siswa X memiliki ciri ADHD (Attention Deficit Hyperactivity Disorder). Gangguan berbahasa tersebut menjadi hambatan bagi Siswa X untuk mendapatkan informasi serta berbicara secara lisan. Hal ini jelas akan memberikan dampak negatif terhadap perkembangan berbahasa serta kecerdasan dan prestasi siswa di sekolah. Adapun tahapan-tahapan dalam penelitian studi kasus ini adalah (1) identifikasi kasus; (2) identifikasi masalah; (3) diagnosis, (4) prognosis; (6) remedial, dan (7) evaluasi.

Hasil studi menunjukkan bahwa (1) gangguan bahasa atau SLI (Speech or language impairment) yang dialami oleh Siswa $\mathrm{X}$ adalah gangguan berbahasa pada masalah fonologi dan pragmatik; (2) gangguan berbahasa yang terjadi pada Siswa X diakibatkan oleh ketidakfokusan anak pada saat berbicara karena Siswa X memiliki ciri ADHD (Attention Deficit Hyperactivity Disorder); dan (3) terapi wicara yang bisa diberikan kepada Siswa $X$ adalah dengan memberikan layanan khusus dalam proses pembelajaran berbicara. Layanan yang paling tepat diberikan adalah tutor sebaya dan model pembelajaran dengan teknik membaca berulang-ulang serta pengucapan ujaran yang tepat.

\section{Daftar Pustaka}

Alyssa, dkk. Prevalence and Nature of Language Impairment in Children with Attention Deficit/Hyperactivity Disorder. Contemporary Issues in Communication Science and Disorders. Vol. 38, 2011.

Cummings, L. Clinical Linguistics. Edinburgh University Press: Edinburgh. 2008.

Dita, dkk. "Prevalensi Gangguan Pemusatan Perhatian dan Hiperaktivitas pada Siswa dan Siswi Sekolah Dasar Negeri Kecamatan Padang Timur Kota

Padang Tahun 2013”. Jurnal Kesehatan Andalas. Vol. 3, No. 2, 2014.

Hikmawati, I. dan Hidayati, E. "Efektivitas Terapi Menulis untuk Menurunkan Hiperaktivitas dan Impulsivitas pada Anak dengan Attention Deficit 
Hyperactivity Disorder (ADHD)”. EMPATHY, Jurnal Fakultas Psikologi, Vol. 2, No 1, Juli 2014.

Hurlock, Elizabeth B. Perkembangan Anak Jilid 1. Jakarta: Erlangga. 1978.

Khoiriyah, dkk. "Model Pengembangan Kecakapan Berbahasa Anak yang Terlambat Berbicara (Speech Delay)". Jurnal Ilmiah Mahasiswa Pendidikan Anak Usia Dini, Vol. 1, No. 1, Agustus 2016.

Kholid A. dan Bachari, Andika Dutha. Dasar-Dasar Psikolinguistik. Bandung: UPI Press. 2009.

Safaa, dkk. "Language Impairment in Attention Deficit Hyperactivity Disorder in Preschool Children". The Egyptian Journal of Medical Human Genetics, Vol. 14, Issues 4, Oktober 2013.

Sunanik. Pelaksanaan Terapi Wicara dan Terapi Sensori Integrasi pada Anak Terlambat Bicara. Nadwa | Jurnal Pendidikan Islam. Vol. 7, No. 1, April 2013.

Syamsuddin \& Damaianti. Metode Penelitian Pendidikan Bahasa. Bandung: PT. Remaja Rosdakarya. 2009.

Sun, Lei dan Wallach, Geraldin P. "Language Disorders Are Learning Disabilities Challenges on the Divergent and Diverse Paths to Language Learning Disability”. Top Lang Disorders, Vol. 34, No.1, 2014. 